\title{
MICONIA RUFINERVIS (MELASTOMATACEAE: MICONIEAE), AN ENIGMATIC ENDEMIC OF THE MASSIF DE LA HOTTE, HAITI
}

\author{
Walter S. Judd \\ Department of Biology and Florida Museum of Natural History \\ University of Florida, Gainesville, Florida 32611, U.S.A. \\ lyonia@ufl.edu
}

ABSTRACT

\begin{abstract}
An updated description of this enigmatic species, an endemic to the Massif de la Hotte, Haiti, is provided, and the presence of axillary inflorescences is reported for the first time. Miconia rufinervis likely belongs within the Caribbean clade of Miconieae; however, its placement within this clade is problematic, although it does show some features of Miconia sect. Calycopteris. Axillary inflorescences are present in M. rufinervis, although these are quite uncommon within the Caribbean clade. Finally, the species is distinctive in the morphology of the multicellular hairs of its stems and leaves, i.e., they are elongate, eglandular, ferrugineous, and provided with numerous short, ascending side branches.
\end{abstract}

KEY WORDS: Miconia rufinervis, Melastomataceae, Miconieae, Massif de la Hotte, Haiti

\section{RESUMEN}

Se aporta una descripción puesta al día de esta enigmática especie, un endemismo del Macizo de la Hotte, Haití, y se reporta por primera vez la presencia de inflorescencias axilares. Miconia rufinervis probablemente pertenece al clado caribeño Miconieae; sin embargo, su emplazamiento en este clado es problemático, aunque muestra algunas características de Miconia sect. Calycopteris. Las inflorescencias axilares están presentes en M. rufinervis, aunque son muy poco comunes en el clado caribeño. Finalmente, la especie es distintiva en la morfología de los pelos multicelulares de sus tallos y hojas, ej., son alargados, eglandulares, ferrugíneos, y provistos de numerosas ramas laterales cortas y ascendentes.

Miconia rufinervis is an enigmatic species endemic to the Massif de la Hotte, Haiti, a region of exceptional diversity of Melastomataceae (Judd 1987; Majure et al. 2013a; Majure, in prep.; Timyan et al. 2017), including 37 endemic taxa of the megadiverse genus Miconia Ruiz \& Pav. (Goldenberg et al. 2013; Michelangeli et al. 2018), i.e., Miconia abscondita Skean \& Judd, M. alloeotricha (Urb.) Judd, Penneys \& Skean, M. apiculata Urb. \& Ekman, M. ayisyena Skean, Judd \& Majure (= Mecranium haitiense Urb.), M. barkeri Urb. \& Ekman, M. blancheana Urb., M. cineana Majure, Judd, Ionta \& Skean, M. cinereiformis Ionta, Judd, \& Skean, M. cordieriorum Ionta \& Judd, M. crassinervis (Urb.) Skean, Judd \& Majure, M. curvipila (Urb. \& Ekman) Ionta, Judd, \& Skean, M. erikmaniana Skean \& Judd (= Calycogonium ekmanii Urb.), M. formonensis (Judd, Skean \& Clase) Judd, Bécquer, \& Majure, M. hotteana (Urb. \& Ekman) Judd \& Ionta, M. hottensis Ionta, Judd, \& Skean, M. hypioides Urb. \& Ekman, M. juddii (Skean) Skean, M. leptantha Urb. \& Ekman, M. macayana Judd \& Skean, M. microdictya (Urb. \& Ekman) Skean, Judd \& Majure, M. navifolia Ionta, Judd, \& Skean, M. ossaeifolia Urb. \& Ekman, M. pagnolensis Majure \& Judd, M. plicatifolia Skean, Judd \& Majure, M. polychaeta (Urb. \& Ekman) Ionta, Judd, \& Skean, M. pycnantha (Urb. \& Ekman) Ionta, Judd, \& Skean, M. revolutifolia Skean, Judd \& Majure (= Mecranium revolutum Skean \& Judd), M. rubrisetulosa Ionta, Judd, \& Skean (= Sagraea setulosa (Urb.) Alain), M. rufistella Judd \& Majure (= Calycogonium apiculatum Urb. \& Ekman), M. rufoalpestris Skean, Judd \& Majure (= Mecranium alpestre Urb. \& Ekman), M. subcompressa subsp. plumieri (Urb. \& Ekman) Judd, Majure \& Ionta, M. tetrazygioides Urb. \& Ekman, M. torbeciana (Urb. \& Ekman) Skean \& Judd, M. tricostata (Urb. \& Ekman) Skean, M. woodsii (Judd \& Skean) Ionta, Judd, \& Skean, and M. xenotricha Urb. \& Ekman. Miconia has more endemics in the Massif de la Hotte than any other angiosperm genus; Pilea is second with 19 endemic species.

Miconia rufinervis was described by Urban and Ekman (Urban 1929) on the basis of more or less nonreproductive material and is here provided with an updated description (including a more detailed description of the multicellular hairs and very immature inflorescences). It is interesting that Urban and Ekman failed to mention in their description that the inflorescences are axillary, although their placement of the species within 
Ossaea and its comparison with Miconia hotteana (Urb. \& Ekman) Judd \& Ionta (= Ossaea hotteana Urb. \& Ekman) suggests that they had observed the very immature axillary inflorescences evident on the type material. The species is phenetically distinctive on the basis of its axillary inflorescences and unusual multicellular hairs, which are elongate, eglandular, ferrugineous, and provided with numerous short, ascending lateral branches. It is also noteworthy that the tertiary and higher-level veins are raised and reticulate on the abaxial leaf surface. These characters, taken together, immediately distinguish it from any other member of the Miconieae occurring in the Greater Antilles.

Liogier considered Miconia rufinervis to be of unknown generic placement, and thus maintained the species as Ossaea rubrinervis Urb. \& Ekman in his "La Flora de la Española" (Liogier 2000); given the generic treatments of Miconieae of that time, his conclusion was sound. However, the current acceptance of a broadly circumscribed Miconia (Gambia \& Almeda 2014; Goldenberg et al. 2013; Ionta et al. 2012; Judd et al. 2014a, b, 2015; Majure et al. 2014; Michelangeli et al. 2016, 2018; Skean et al. 2018), based on recent phylogenetic analyses (e.g., Goldenberg et al. 2008; Michelangeli et al. 2008), allows a rather straightforward placement of the species within Miconia because of its phenetic similarity to the numerous other members of the Miconia clade (although I note that the diagnostic characters of berry fruits and stamens with poorly developed anther connectives are not available on the type material). The classificatory problem, however, simply has been shifted to a lower level—in which subclade of Miconia should the species be placed?

Miconia rufinervis is very likely a member of the Caribbean clade (as designated in Goldenberg et al. 2008; Michelangeli et al. 2008). This clade is quite diverse in the Greater Antilles (containing species traditionally placed within Calycogonium DC., Pachyanthus A. Rich., Tetrazygia Rich. ex DC., Charianthus D. Don, and Clidemia D. Don p.p., Miconia p.p. and Ossaea DC. p.p.). Miconia rufinervis is phenetically similar to species within this clade, which represents one of the major radiations within the Antilles (Michelangeli et al. 2008). It also has stems with nodal lines, a putative morphological synapomorphy of the Caribbean clade (Majure et al. 2013b), although this feature is quite homoplasious, limiting its taxonomic utility. Additionally, it is excluded from the three other major Antillean radiations (Michelangeli et al. 2008): Miconia sect. Sagraeoides (Skean) Skean, Judd, Majure \& Ionta (often treated as Mecranium Hook.f.; i.e., it lacks the minute, thin-walled glandular hairs and the elongate, unbranched to branched, thin-walled hairs so characteristic of this clade; Skean 1993, fig. 3, see also Judd et al. 2015 and Skean et al. 2018); Miconia sect. Chaenopleura (Rich. ex DC.) Benth. \& Hook.f. (which has terminal inflorescences; Judd 2007); and Miconia sect. Sagraea (DC.) Ionta, Judd, \& Skean (Sagraea-type hairs are absent in M. rufinervis; Ionta et al. 2012). These four clades also differ in many reproductive features (see cited references) but these distinctions cannot be applied in comparisons with $M$. rufinervis. All four clades are well diversified in the Massif de la Hotte, with the region supporting 11 endemic species of sect. Sagraea, nine of sect. Sagraeoides, eight of sect. Chaenopleura, and seven of the Caribbean clade.

The precise phylogenetic placement of M. rufinervis within the Caribbean clade, however, is unclear. Axillary inflorescences occur only in a few species of the Caribbean clade, i.e., Miconia vegaensis (Cogn.) Judd, Bécquer, \& Majure, M. reticulatovenosa Judd, Bécquer, \& Majure, and M. maculata (Urb. \& Ekman) Judd, Bécquer, \& Majure of Miconia sect. Calycopteris Judd, Bécquer, \& Majure (Bécquer et al. 2017/18; Judd et al. 2014a); M. glomeruliflora Judd, Bécquer, \& Majure and M. lanatifolia Judd, Bécquer, \& Majure of sect. Echinatae Judd, Bécquer, \& Majure (Majure et al. 2015); Miconia leblondii Judd \& Skean (traditionally Charianthus nodosus (Desr.) Triana) of the Charianthus clade (Penneys \& Judd 2006); and Miconia cupeyalensis Bécquer \& Michelang. (= Calycogonium floribundum Borhidi) and M. pseudofloribunda (Bécquer) Bécquer \& Michelang. (Bécquer 2011) of an as yet unnamed clade of ten Cuban and Hispaniolan species characterized by a ferrugineous indumentum of globular-stellate to stellate hairs and 4-merous flowers with the calyx teeth exceeding to much exceeding the calyx lobes. Its placement within the Charianthus clade is unlikely due to the presence of druse crystals (which are lacking in the Charianthus clade) and elongate multicellular hairs with short, ascending lateral branches (vs. the flattened-stellate hairs diagnostic of the Charianthus clade). Species of sect. Echinatae have bulla-based hairs on their stems and leaves (and also hypanthia), and these hairs lack short, lateral branches; in contrast, the elongate hairs of M. rufinervis are not bulla-based and are shortly branched. 
Additionally, the abaxial leaf surfaces of all species of sect. Echinatae have short, globular-stellate hairs, and such hairs are absent in M. rufinervis. Confirmation of a relationship (or lack of one) in regards to sect. Calycopteris must await the discovery of fertile material, as the putative synapomorphies of that clade are entirely based on reproductive features (Bécquer et al. 2017/18; Judd et al. 2014). Interestingly, several species of sect. Calycopteris do have adaxial leaf surfaces drying much darker than the abaxial, a characteristic also seen in M. rufinervis. Affinities with sect. Calycopteris, therefore, cannot be ruled out at this time; however, no species within that section has hairs at all similar to those of M. rufinervis. Confirmation of a phylogenetic relationship with the clade containing M. cupeyalensis and M. pseudofloribunda also requires fertile material, although the elongated and shortly-branched hairs of M. rufinervis are unlike those found in these species.

Finally, it is puzzling that Urban (1929) compared M. rufinervis with Miconia hotteana (of sect. Sagraea). The two species differ in leaf shape and indumentum (i.e., ovate, with acuminate to acute apices and acute to obtuse bases in M. hotteana, and with Sagraea-type glandular hairs and lacking elongate multicellular hairs; compare with description of M. rufinervis). Miconia hotteana also has fasciculate inflorescences, while those of M. rufinervis have fairly elongated peduncles. It is noteworthy, however, that elongated multicellular hairs (moderately roughened) are present in some other members of sect. Sagraea (e.g., M. scabrosa Ionta, Judd, \& Skean; see Wurdack 1986, fig. 119). Miconia scabrosa differs from M. rufinervis in its fasciculate inflorescences and most strikingly, in the presence of elongate, conic, multicellular, bulla-based hairs on the adaxial leaf surface.

The species of Melastomataceae growing in the Massif de la Hotte have been studied and/or collected by several botanists in the late $20^{\text {th }}$ and early $21^{\text {st }}$ century (e.g., John L. Clark, Gretchen M. Ionta, Lucas C. Majure, J. Dan Skean, Jr., Joel C. Timyan, and myself), and thus it is a concern that Miconia rufinervis has not been recollected, especially because Erik Ekman indicated (on the specimen label of the type) that the species was "not too rare." Unfortunately, the species is not unique in this regard. Miconia abscondita (Judd et al. 2015; of sect. Sagraeoides), collected by Ekman in 1926 in the Massif de la Hotte, also awaits rediscovery and is known only from vegetative material. Miconia plicatifolia (Skean 1993; Skean et al. 2018; also of sect Sagraeoides) was collected by Ekman in 1917 in the Massif de la Hotte; it also has not been rediscovered and is known only from fruiting material. Miconia leptantha (Judd 2007; of sect. Chaenopleura) was collected by Ekman in 1928 in the Massif de la Hotte, and has not been recollected, but fortunately is known from beautiful flowering material. Miconia pycnantha (Ionta et al. 2012; of sect. Sagraea) is known only from the type gathering (flowering material); it was collected in the Massif de la Hotte by Ekman in 1928. Interestingly, M. hotteana, the species to which Urban and Ekman compared M. rufinervis (Urban 1929), also has not been seen by systematists since its original collection (in the Massif de la Hotte, 1927) by Ekman. Thus, of the 37 species of Miconia endemic to the Massif de la Hotte, five are known only from the type gatherings. Clearly, more fieldwork in Haiti is warranted, especially in the species rich mountains in the southern part of the country (Massif de la Hotte and Massif de la Selle)!

TAXONOMIC TREATMENT

Miconia rufinervis Judd in Michelang. et al., Brittonia 71(1):112. 2019. DOI 10.1007/s12228-018-9546-0. (Fig. 1). Ossaea rubrinervis Urb. \& Ekman, Ark. Bot. 22A(17):57. 1929. Type: HAITI: Massif de la Hotte, western group, Les Roseaux, Hab. Quillaud, in thickets, not too rare, ca. 1200 m, 27 Jun 1928, E.L. Ekman H10120 (ноLотүPE: S!; ISотуPES: K(000329548) digital image!, NY(00099713) digital image!, US (00779515) digital image!). Non Miconia rubrinervis (Naudin) Judd \& Bécquer.

Note.-The new name M. rufinervis Judd was proposed in Michelangeli et al. (2019) because the epithet "rubrinervis" is not available in Miconia.

Evergreen shrub up to $1.5 \mathrm{~m}$ tall. Young stems slightly quadrangular, the indumentum of dense to moderate, short to elongate, eglandular, ferrugineous, multicellular hairs, each globular-stellate or elongated and with numerous projections or short, lateral, ascending branches, to $1.4 \mathrm{~mm}$ long, internodes $4-8 \mathrm{~cm}$ long, lacking longitudinal ridges, but with faint nodal lines. Leaves isophyllous or nearly so; petiole $1.3-3 \mathrm{~cm}$ long, the indumentum of dense short to elongated, ferrugineous hairs (similar to those of the leaf and stem), the blade 4.7-12 $\times 3-8 \mathrm{~cm}$, ovate, chartaceous to slightly coriaceous, the apex obtuse to rounded-mucronate, the base cordate to 


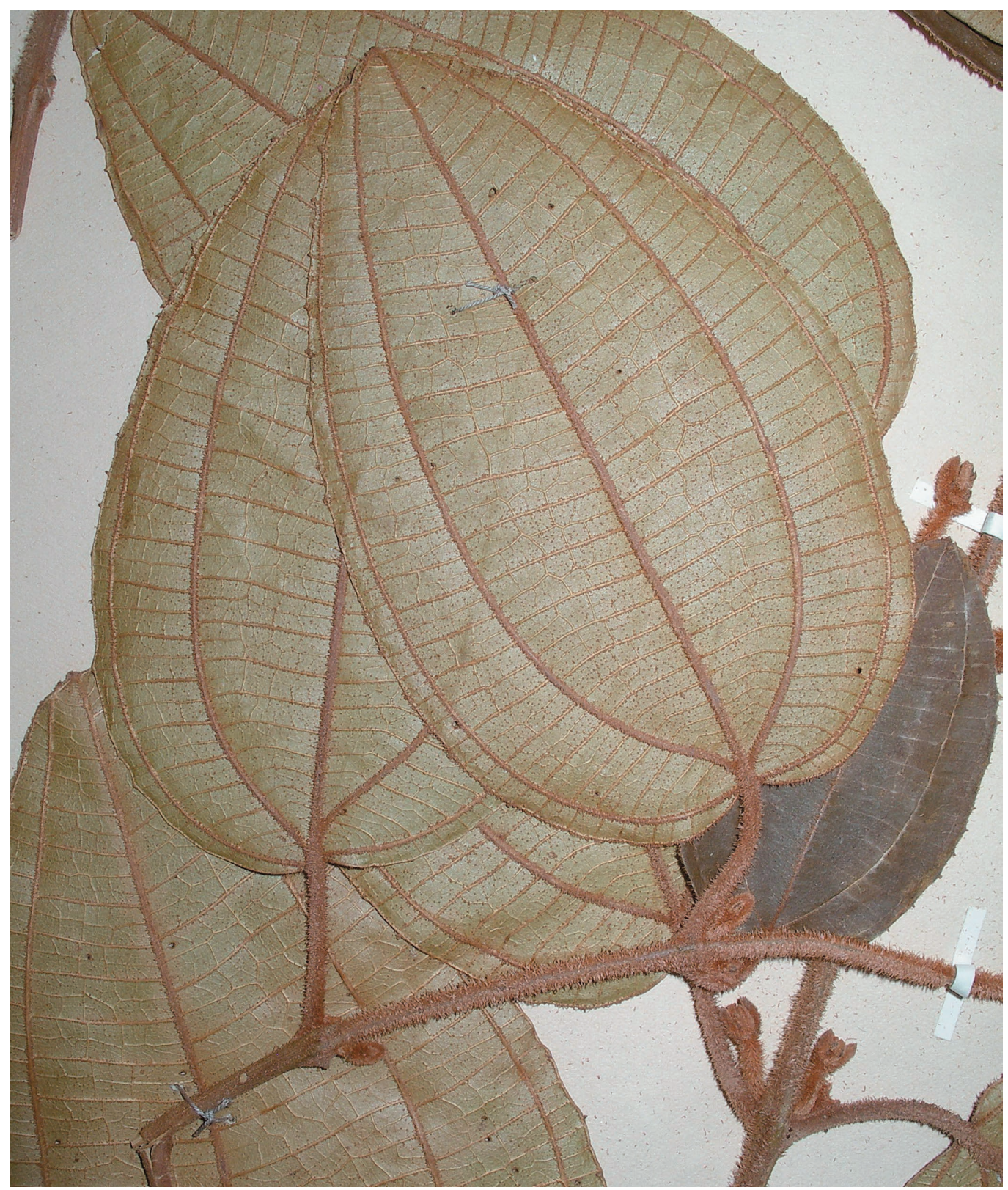

FIG. 1. Miconia rufinervis. Note leaves with adaxial surface dark, abaxial surface pale green with conspicuous, raised, ferrugineous-pubescent, primary, secondary and tertiary veins, and axillary inflorescences (Ekman H10120).

rounded, the margin plane to slightly revolute, dentate to serrate-dentate, with the teeth to $0.4-0.7 \mathrm{~mm}$ long, and teeth and margin associated with \pm elongate hairs; secondary veins in 3 pairs, 2 pairs conspicuous and 1 pair inconspicuous, acrodromous, \pm basal, the innermost pair joining midvein $1.5-5 \mathrm{~mm}$ above the leaf base, the innermost conspicuous secondary veins placed $5.5-18 \mathrm{~mm}$ in from margin, the outermost conspicuous secondary veins placed $1-4.5 \mathrm{~mm}$ in from margin, the inconspicuous secondary veins \pm intramarginal, 
tertiary veins percurrent, oriented subperpendicular to midvein, 2-6 $\mathrm{mm}$ apart, connected by quaternary veins, the higher order veins reticulate, the adaxial surface with the midvein and major secondary veins slightly impressed, tertiary veins \pm flat, remaining veins flat, the abaxial surface with midvein strongly raised, the major secondary veins strongly raised, the minor secondary veins and tertiary veins moderately raised, the quaternary veins slightly raised, and the higher order veins very slightly raised to nearly flat; adaxial surface green, appearing dull, \pm smooth, and drying noticeably darker than the abaxial surface, the indumentum initially of globular-stellate to elongate and laterally short-branched hairs, but very quickly glabrescent, although elongate and laterally short-branched hairs retained on midvein and major secondary veins; lamina with scattered druse crystals; abaxial surface pale green, the surface nearly smooth but with prominent raised-reticulate higher-order veins, with \pm sparse globular-stellate to elongate, eglandular, ferrugineous, multicellular hairs with short lateral, ascending branches, and the veins with dense to sparse, globular stellate to very elongate, eglandular, ferrugineous, multicellular hairs with short lateral, ascending branches, to $0.7 \mathrm{~mm}$ long, and hairs of both lamina and veins \pm persistent (and the more densely pubescent major veins thus contrasting with the paler lamina). Inflorescences axillary (but only very immature inflorescences observed), these probably reduced cymes, the peduncle $1.3-2.3 \mathrm{~cm}$ long, densely covered with elongated, short-branched hairs; bracts 2-5 $\times$ ca. $1 \mathrm{~mm}$, the first pair larger than the others, \pm linear, with acute apex, densely covered with elongated, short-branched hairs; bracteoles 1-1.5 × 0.7-0.8 mm, \pm triangular, with acute apex, with sparse elongated, short-branched hairs. Flowers and fruits unknown.

Distribution and habitat.—Endemic to the Massif de la Hotte, most likely in rak bwa (i.e., moist broadleaved forest on limestone) at ca. $1200 \mathrm{~m}$. For detailed descriptions of the rak bwa community see Judd (1987) and Judd et al. (1990, 1998).

Additional specimens examined. Species only known from the type.

The specific epithet "rufinervis" refers to the appearance of the midvein, major secondary and tertiary veins on the abaxial leaf surface, which appear rusty red because of their more or less dense covering of multicellular, elongated, ferrugineous, shortly-branched hairs, contrasting with the pale green surface of the abaxial epidermis. Additionally, it is meant to evoke the original epithet "rubrinervis."

\section{ACKNOWLEDGMENTS}

I thank Lucas Majure, Keeper of the University of Florida Herbarium (FLAS) and Kent Perkins, Collections Manager, for assistance in processing and use of specimens. I thank the curator of the Stockholm herbarium (S) for the loan of the holotype of Ossaea rubrinervis. This research was supported, in part, by National Science Foundation Grant BSR-0818399. I appreciate the helpful comments of Eldis Bécquer and Gretchen M. Ionta, who reviewed an earlier version of the paper.

\section{REFERENCES}

BÉCQUER, E.R. 2011. Calycogonium pseudofloribundum, a new species of Melastomataceae, Miconieae, from eastern Cuba. Willdenowia 41:289-294.

Bécquer, E.R., W.S. Judd, \& L.C. Majure. 2017/18. Taxonomic revision of Miconia sect. Calycopteris (Melastomataceae, Miconieae) in Cuba. Brittonia 70:90-110. DOI 10.1007/s 12228-017-9493-1.

Gambia, D. \& F. Almeda. 2014. Systematics of the Octopleura Clade of Miconia (Melastomataceae: Miconieae) in Tropical America. Phytotaxa 179:1-174.

Goldenberg, R.D., D.S. Penneys, F. Almeda, W.S. Judd, \& F.A. Michelangeli. 2008. Phylogeny of Miconia (Melastomataceae): Patterns of stamen diversification in a megadiverse Neotropical genus. Int. J. PI. Sci. 169:963-979.

Goldenberg, R.D., M.K. Caddah, A.B. Martius, J. Meirelles, F.A. Michelangeli, \& M. Weiss. 2013. Nomenclature botanicus for the Neotropical genus Miconia (Melastomataceae: Miconieae). Phytotaxa 106:1-171.

IONTA, G.M., W.S. Judd, J.D. SkEAN, JR., \& C.K. McMullen. 2012. Two new species of Miconia sect. Sagraea (Melastomataceae) from the Macaya Biosphere Reserve, Haiti, and twelve relevant new species combinations. Brittonia 64:61-72.

Judd, W.S. 1987. Floristic study of Morne La Visite and Pic Macaya National Parks, Haiti. Bull. Florida State Museum, Biol. Sci. 32(1):1-136. 
JUDD, W.S. 2007. Revision of Miconia sect. Chaenopleura (Miconieae, Melastomataceae) in the Greater Antilles. Syst. Bot. Monogr. 81:1-235.

Judd, W.S., J.D. SkEAN, JR., \& C.K. McMullen. 1990. The flora of Macaya Biosphere Reserve: Additions, taxonomic and nomenclatural changes. Moscosoa 6:124-133.

JudD, W.S., J.D. SKEAN, JR., \& D.G. GRIFFIN, III. 1998. The flora of Macaya Biosphere Reserve: Additional taxa, taxonomic and nomenclatural changes, II. Moscosoa 10:114-120.

Judd, W.S., E.R. Bécquer, \& L.C. Majure. 2014a. Taxonomic studies in the Miconieae (Melastomataceae). XI. A revision of Miconia sect. Calycopteris on Hispaniola. Brittonia 66:216-249.

Judd, W.S., E.R. Bécquer, J.D. SkeAn, JR., \& L.C. Majure. 2014b. Taxonomic studies in the Miconieae (Melastomataceae). XII. Revision of Miconia sect. Miconiastrum, with emphasis on the Miconia bicolor complex. J. Bot. Res. Inst. Texas 8:457-491.

Judd, W.S., L.C. Majure, J.D. SkeAN, JR., \& K.M. Neubig. 2015. Miconia abscondita (Melastomataceae: Miconieae), a new species from the Massif de la Hotte, Haiti: Rediscovered in herbaria after being hidden for nearly nine decades. Rhodora 117:317-341.

LıogieR, A.H. 2000. La flora de la Española. Vol. IX. Melastomataceae. Jardin Botánico Nacional "Dr. Rafael Ma. Moscoso." Instituto Tecnológico de Santo Domingo, Santo Domingo, República Dominicana.

Majure, L.C., G.M. Ionta, J.D. Skean, JR., \& W.S. Judd. 2013a. New records and notes on species from Parc National Pic Macaya, Massif de la Hotte, Haiti, including a new species of Pilea (Urticaceae). J. Bot. Res. Inst. Texas 7:681-691.

Majure, L.C., W.S. Judd, G.M. Ionta, J.D. Skean, Jr., E.R. Bécquer, J. Burke, D.S. Pennneys, G. Ocampo, M. Alvear, M. Goldenderg, R. Almeda, \& F. Michelangeli. 2013b. Evaluating morphological evolution in tribe Miconieae (Melastomataceae): Homoplasy is the rule not the exception. Botany 2013. Abstract ID 300.

Majure, L.C., W.S. Judd, G.M. Ionta, J.D. Skean, JR., K.M. Neubig, \& E.R. Bécquer. 2014. Miconia cineana, a new species from the Massif de la Hotte, Haiti, based on morphological and molecular evidence. Syst. Bot. 39:906-914.

Majure, L.C., K.M. Neubig, J.D. Skean, JR., E.R. Bécquer, \& W.S. Judd. 2015. Evolution of the sandpaper clade (Miconieae, Melastomataceae). Int. J. PI. Sci. 176:607-626.

Michelangeli, F.A., W.S. Judd, D.S. Penneys, J.D. Skean, JR., E.R. Bécquer, R. Goldenberg, \& C.V. Martin. 2008. Multiple events of dispersal and radiation of the tribe Miconieae (Melastomataceae) in the Caribbean. Bot. Rev. 74:53-77.

Michelangeli, F.A., F. Almeda, M. Alvear, E.R. Bécquer, J. Burke, M.K. Caddah, R. Goldenberg, G.M. Ionta, W.S. Judd, L.C. Majure, J. Meirelles, A.N. Nicolas, G. Ocampo, D.S. Penneys, J.D. Skean, JR., \& C. Ulloa Ulloa. 2016. Proposal to conserve Miconia nom. cons. against the additional names Maieta and Tococa (Melastomataceae: Miconieae). Taxon 65:892-893.

Michelangeli, F.A., R. Goldenberg, F. Almeda, W.S. Judd, E.R. Bécquer, G. Ocampo, G.M. Ionta, J.D. Skean, JR., L.C. Majure, \& D.S. PenNeYs. 2019. Nomenclatural novelties in Miconia (Melastomataceae: Miconieae). Brittonia 71(1):82-121. DOI 10.1007/s12228-018-9546-0.

Penneys, D.S. \& W.S. Judd. 2006. A systematic revision and cladistic analysis of Charianthus (Melastomataceae) using morphological and molecular characters. Syst. Bot. 30:559-584.

SKEAN, J.D., JR. 1993. Monograph of Mecranium (Melastomataceae-Miconieae). Syst. Bot. Monogr. 39:1-116.

SKEAN, J.D., JR., W.S. JUdD, L.C. MAJURE, \& G.M. IONTA. 2018. Recognition of Miconia sect. Sagraeoides (Melastomataceae: Miconieae) and associated nomenclatural changes. Brittonia 70(3):342-355. DOI 10.1007/s12228-018-9531-7.

Timyan, J.C., W.S. Judd, K.D. Perkins, \& N.H. Williams. 2017. Flora of Macaya National Park, Haiti. A Museum Voices Site, Florida Museum of Natural History. www.floridamuseum.ufl.edu/museum-voices/macaya/.

URBAN, I. 1929. Plantae Haitienses et Domingenses novae vel rariores VII. a cl. E.L. Ekman 1924-1928 lectae. Ark. Bot. 22A (17):1-115 [Ossaea rubrinervis, pp. 59-60].

WURDACK, J.J. 1986. Atlas of hairs for Neotropical Melastomataceae. Smithsonian Contr. Bot. No. 63. Smithsonian Institution Press, Washington, D.C., U.S.A. 